\title{
TOTAL QUALITY MANAGEMENT IN EDUCATION
}

\author{
Tara Bahadur Thapa \\ Department of EPM
}

\begin{abstract}
Total Quality Management (TQM) is the latest in a parade of models, recipes, programs, frameworks, and slogans for guiding academic reform. It provides a tool to help ensure this quality. The management in TQM means everyone is the manager of their own responsibilities because everyone in the institution, whatever their status, position or role is. Information and technologies have brought sea changes in education and has therefore changed the interpretation of the term quality. TQM advocates that everything and everybody in the organization is involved in the academic institutions for continuous improvement. As it is applied to education, TQM faces new challenges due to diversity in nature of students and educators, large and multileveled classrooms, technological advances and new paradigms in educational content and delivery. Despite these issues education must maintain quality across classrooms, schools and institution. This article highlights the need of TQM to improve overall quality of education in Nepal.
\end{abstract}

\section{Keywords}

Total Quality Management, managerialsim, educational management, quality improvement, application

\section{Introduction}

Quality education is associated with excellence or conformance to specific standards. Excellence has governed quality education for a long time. Later, satisfaction replaced excellence to denote quality in the beginning of the 21st century.

Total quality management (TQM) is a philosophy and system for continuously improving the servicesand/or products offered to customers. It is a management system for a customer focused organization that involves all employees in continual improvement of all aspects of the organization. Bush (2003) points out that TQM means satisfying the customers first time and every time. Its management approach of an organization 
centered on quality based on the participation of all of its members aiming at long term success through customer satisfaction and benefits to all members of the organization and to the society. Accordingly, TQM is an organization-wise approach to continuously improve the quality of the organizations, processes, products and services (Thapa, 2067 B.S). Further, the management in TQM implies that it is a management approach, not just a narrow quality control or quality assurance function. It should be remembered that everyone in the organization is involved in TQM not just the project head. In other words it is a very people-oriented and has many implications for the study and application of institutional behavior.

\section{TQM: from industry to education}

TQM is applied in education as in business and industry. In an attempt to define TQM in the educational context, Murgatroyd and Morgan (1993) stated that it as a systematic management of an organization's customersupplier relationships in such a way as to ensure sustainable, steep-slope improvement in quality performance. They argued that TQM should be viewed in a holistic manner. Mokupadhyay (2005) contends that a partisan or fragmented way of looking at quality in any academic sector is neither desirable, nor feasible, for an action in one area sets out a chain of reactions in several other areas of management of an educational institution. It provides an important opportunity to look at quality in a holistic fashion and also instrumentalities for managing quality. Convinced with the fact that TQM is not an agenda of only the top management as opposed to other hierarchical management principles, Sallis (2002) inscribed, "The total in TQM dictates that everything and everybody in the organization is involved in the enterprise of continuous improvement".

Theories and practices in educational management as a field of study were derived from management principles originally applied in the industry (Bush, 2003). This is because educational management, as a field of scholarly endeavor, developed later than related fields, such as business administration and public administration. These theories and principles were carefully modified in order to fit in the educational settings. Hence, in order to fully understand the underlying concepts in a particular theory and practice in education administration, it is important to explore its origin and impacts in the industry - where it came from. As TQM derived its language, concepts, and methodology from industry, it is therefore important to investigate how it started in the industry. This way, we will have better understanding of how it permeated in the educational setting. Moreover, the distinction between productoriented industries and service-oriented educational institutions can be established when there is thorough understanding of how TQM gained popularity in the industry and then in education.

TQM achived its first success in Japan during the post-World War II rehabilitation. It was introduced by an American statistician, W. Edwards Deming, who first visited Japan in the late 1940s to work in their post-war census (Sallis, 2002). The idea was embraced by the Japanese where they started applying it in the manufacturing of goods and then followed by service industries. From then on, Japanese industries became popular icons in the world when it comes to product quality.

However, the historical movement of total quality in education is of more recent origin as there were only few references in the literature before the late 1980. Sallis (2002, p. ) clearly narrated the beginning of TQM in education in the USA and the UK. He divulged, "Much of the pioneering work on TQM was carried out in the USA and by further education colleges in the UK. The US initiatives developed somewhat before those in Britain, but in both countries the surge of interest occurred from 1990 onwards."

TQM, a new management system/ new managerialism refers to neo-liberalism. Improvement in education is necessary 
and commitment to strive for it is one of the strategies for creating continual change (Schomoker, \& Wilson, 1993). New managerialism relies on requiring compliance and individual desires to shape their own direction within a structure and it partially disguise the correction by pacing increase emphasis on personal responsibility within a new system of institutions. Traditional schools are managed undersmall management system, which replaces the TQM nowadays. TQM focus on quality education thesis has brought five contending perspectives viz. zero defect production, satisfaction, self determined, just in time and suppliers partnership perspectives (Koirala, 2003). According to the Besterfield, and Tribus (1995) there are five pillars of TQM : product, process, organization, leadership and commitment and each pillar depends upon other four, because TQM is a holistic and integrated approach it encourage encompasses before during after the fact action that are related to management.

TQM was first applied in the higher education level but it later gained prominence in the entire levels of education specifically in the basic level where schools. However, even if TQM is proven to be applicable in education institutions, extra cautions must still be observed when applying concepts and practices from industry to education.

\section{Applications of TQM in education}

TQM has become essential in academic organizations. It is the total integrated effort for gaining improvement in every facet of organizational activities. Some of the most commonly contributions of TQM in education are as follows:

To adopt a new philosophy: TQM is a new managerialism approach which may include new teaching and learning strategies that aim at success of every learner (Davies, 2003). In tne contxt of Nepal, Headteachers other stakeholders of education need to make a long commitment to their school to ensure that all activities are to ensure specific and fundamental rights. It provides an appropraite atmosphere in which educational rights are maintained and reinforced.

To increase accountability: People associated with in educational management are more accountable to the society. They develop a deep sense of belongingness to the educational institutions. TQM is a system which focuses on continuous growth and improvement of institution, parental involvement in education, contribution of their time, labor, materials and land, participation in decision making process and monitoring of teacher performance.

To identify and address problems: TQM can help identify and address factors that cause educational problems. In that institutions, there may be different problems such as low participation, dropouts, repetition, poor academic performance and poor management styles. TQM stresses a systematic, integrated, consistent and organization-wise perspective to resolve problems.

To increase management: Until now most of the public academic institutions like schools and colleges lack even basic supplies of educational materials. In the beginint of every academic session, lack of materials, physical infrastructures and human resources become headlines in the media in Nepal. TQM focuses on the managerial part of the educational sectors continuously involving all managerial hierarchy of education.

To increase teaching learning process: TQM does not only focus on the managerial parts but also on teaching learning process in classrooms. It is a strategy for continuous classroom teaching. It also helps to maintain quality in examination of various standards which leads to service quality, and effective teaching.

\section{Conclusive understanding about TQM in education}

There are some difficulties in implementing TQM in education. For example, there is often a conflict between administration and 
academic functions. The two groups often form parallel worlds without a shared vision or mission for the school. A total quality approach requires that the two groups work together to meet customer expectations. Similarly the concept of involving guardian in education may be difficult to adopt. TQM may not be implementable if there is lack of leadership, teacher and Students' Unions misunderstanding and it also fails if it fails to ensure the participation of guardians and other stakeholders of education (Kaufman, and Zahn. 2010).

In spite of the arguments against TQM, many educational institution have achieved positive results from it. A growing number of institutions in the USA and other developed countries have implemented the process, principle and tools of TQM (Binkley,1994).). All stakeholders of education including head teachers, local governing bodies, school management committees, resource centers to need to be involved to improve quality of education. Quality education with satisfaction of students and their guardians or consumers should be a priority for Nepalese people and government sector and much of the national budget as well as international aids are spent in this sector. Despite enormous financial investment in education, there has been a distressing lack of discussion and debate over what has gone wrong in education for decades and therefore, efforts need to be made in that direction in the days to come.

\section{References}

Besterfield, D.\& Tribus, J.(1995). Total quality management. Englewood Cliffs: PrenticeHall, Inc. $\mathrm{s}$
Binkley, B. (1994). Total quality management and its impact on higher education with emphasis on Academic libraries. Unpublished master's thesis, Tennessee State University.

Bush, T. (2003).Theories of educational management (Modules). http//enx./ content./ m13867/latest

Kaufman, R., and . Zahnm D. (2010). Quality management Plus: The Continuous Improvement of Education. Newbury Park: Corwin Press.

Koirala, B.N.(2003). Managing paradoxes: education for the sustained future. Education for Sustainable. Development in Nepal views and vision. vo. 1.151-158.

Davies, F. (2003). New managerial approaches of education. New York: Harper \& Brothers Ltd.

Murgatroyd, S. \& Morgan, C. (1993). Total quality management and the school. Buckingham: Open University press.

Mokupadhyay, M. (2005). Total quality management in school. New Delhi: Sage Publications.

Sallis, E. (2002). Total quality management in education. London: Kogan Page Ltd.

Schomoker, M. \& Wilson, R. (1993). Total quality education: Profiles of schools that demonstrate the power of Deming's management principles. Bloomington: Phi Delta Kappa.

Thapa, T. B. (2068B.S). Educational management and organization behavior . 2nd ed. Kathmandu: Sunlight Publication.

\section{The Author}

Tara Bahadur Thapa teaches various courses on Educational Planning and Management (EPM) in Thakur Ram Multiple Campus, Birgunj. He has published three titles on the areas of Educational Psychology and EPM. He has also published several articles in different journals. His areas of interest include Educational Management and Human Resource Management in Education. 